\title{
Significance of Extracellular Vesicles: Pathobiological Roles in Disease
}

\author{
Seiji Yamamoto $^{1^{*}}$, Erika Azuma ${ }^{1,2}$, Masashi Muramatsu ${ }^{3}$, Takeru Hamashima ${ }^{1}$, Yoko Ishii ${ }^{1}$, and \\ Masakiyo Sasahara ${ }^{1}$ \\ ${ }^{1}$ Department of Pathology, Graduate School of Medicine and Pharmaceutical Sciences, University of \\ Toyama, 2630 Sugitani, Toyama 930-0194, Japan, ${ }^{2}$ Department of Technology Development, Toyama \\ Technology Center, Astellas Pharma Tech Co., Ltd., 2-178 Kojinmachi, Toyama 930-0809, Japan, ${ }^{3}$ Institute \\ of Resource Development and Analysis, Kumamoto University, 1-1-1 Honjo, Kumamoto 860-0811, Japan
}

\begin{abstract}
Over the past decade, many studies have been conducted on extracellular vesicles (EVs) in the fields of basic and clinical research. EVs are small sized membranous vesicles generated from many type of cells upon activation by environmental stresses such as heat, hypoxia, and irradiation. EVs theoretically consist of microparticles/microvesicles, exosomes, and apoptotic bodies by different productive mechanisms. Clinically, EVs are observed in the blood stream of patients suffering from acute and chronic inflammation evoked by various diseases, and number of EVs in blood flow is often dependent on the inflammatory status and severity of the diseases. To date, it has been reported that small molecules such as RNAs and proteins are encapsulated in EVs; however, the functions of EVs are still unclear in the biological, pathological, and clinical aspects. In this review, we summarize and discuss the biogenesis-based classification, expected function, and pathobiological activities of EVs.
\end{abstract}

Key words: Extracellular vesicle, MicroRNA, Endothelial cell, Pericyte

\section{Introduction}

Extracellular vesicles (EVs) are small membranous globules that are released from many cells including endothelial cells, leukocytes, and cancer cells (Kawamoto et al., 2012; Leroyer et al., 2007; Yamamoto et al., 2015). Clinically, the number of EVs has been observed to increase in the bloodstream of patients suffering from acute and chronic inflammation evoked by diseases such as sepsis, stroke, preeclampsia, atherosclerosis, diabetes mellitus, metabolic syndrome, and cancer (Agouni et al., 2008; Boulanger et al., 2006; Koga et al., 2005; Mostefai et al., 2008; Petrozella et al., 2012; Simak et al., 2006). Several studies have reported that EVs mediate intercellular communica-

\footnotetext{
*To whom correspondence should be addressed: Seiji Yamamoto, Department of Pathology, Graduate School of Medicine and Pharmaceutical Sciences, University of Toyama, Toyama 930-0194, Japan.

Tel: +81-076-415-8879, Fax: +81-076-434-5016

E-mail: seiyama@med.u-toyama.ac.jp

Abbreviations: EV, extracellular vesicles; mRNA, messenger RNA; miRNA, microRNA; LPS, lipopolysaccharide; MVB, multivesicular body; $\mathrm{AB}$, apoptotic body; vSMC, vascular smooth muscle cell; MAPK, mitogen-activated protein kinase; VEGF, vascular endothelial growth factor; VEGFR2, vascular endothelial growth factor receptor 2; D114, deltalike ligand 4; Evi, evenness interrupted/wntless; WIS, Wntless; CRP, Creactive protein.
}

tions by releasing encapsulated materials such as messenger RNAs (mRNAs), microRNAs (miRNAs), and proteins, to target cells (Al-Nedawi et al., 2009, 2008; Fujita et al., 2014; Kawamoto et al., 2012; Tominaga et al., 2015; Waldenstrom et al., 2012; Yamamoto et al., 2015). This review summarizes and discusses the current understanding of the pathophysiological role of EVs in various diseases.

\section{Classification of extracellular vesicles}

EVs including microparticles/microvesicles, exosomes, and others (Beyer and Pisetsky, 2010; Gould and Raposo, 2013; Kosaka et al., 2010; Raposo and Stoorvogel, 2013) are released from different cell types by different productive mechanisms (Fig. 1). EVs are commonly classified into three major groups based on their theoretical biogenesis pathways and sizes (Table I) (Gyorgy et al., 2011; Kalra et al., 2012).

\section{Membrane shedding type EVs (microparticles/ microvesicles)}

Platelet dust has been identified in human plasma (Wolf, 1967). This was the first report to describe microparticles/ 


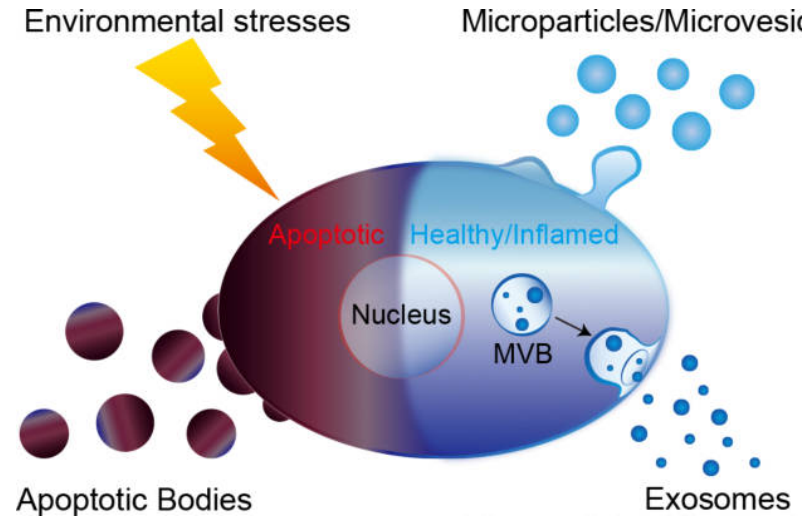

Fig. 1. Mechanisms of extracellular vesicle (EV) production. A major population of EVs is comprised of microparticles/microvesicles, exosomes, and apoptotic bodies. These are produced from different cell types (e.g. vascular endothelial cells and tumor cells) and by different mechanisms of production in response to various stimulating factors. Microparticles/microvesicles are shed and then released from the plasma membranes of cells. Exosomes are internalized in early endosomes called as multivesicular bodies (MVB). When MVBs merge with the plasma membrane and split open, exosomes are released to the extracellular space. Apoptotic bodies are broken off from cells undergoing apoptosis. These EVs can carry bioactive molecules to recipient cells.

microvesicles. When the plasma membrane is activated by extrinsic stimuli such as inflammatory cytokines and lipopolysaccharide (LPS), membranous globular objects of submicron to micron sizes $(0.05-3 \mu \mathrm{m})$ are shed from the plasma membrane surface, and subsequently released (Morhayim et al., 2014; Raposo and Stoorvogel, 2013; Yamamoto et al., 2015). These globular objects comprised of the plasma membrane are categorized as microparticles/ microvesicles among EVs (Fig. 1, Fig. 2 and Table I) (Beyer and Pisetsky, 2010; Yamamoto et al., 2015).

\section{Multivesicular body derived EVs (exosomes)}

Exosomes were firstly discovered in maturing mammalian reticulocytes (Johnstone et al., 1987). In endosomes, a part of the membranous organelles from cells can be internalized into nanometer-sized vesicles $(40-100 \mathrm{~nm})$, in which case the vesicle-filled endosomes are called as multivesicular bodies (MVBs) (Fujita et al., 2014). When MVBs merge with a plasma membrane, and release the nanometersized vesicles into the extracellular space, these small vesicles become exosomes and are classified as a subclass of EVs (Fig. 1, Fig. 2 and Table I) (Beyer and Pisetsky, 2010; Gruenberg and van der Goot, 2006).

\section{Apoptosis derived EVs (apoptotic bodies)}

Cells suffering from many kinds of environmental stresses undergo apoptosis (Steller, 1995). Apoptotic bodies (ABs), found as membranous vesicles of relatively large diameter

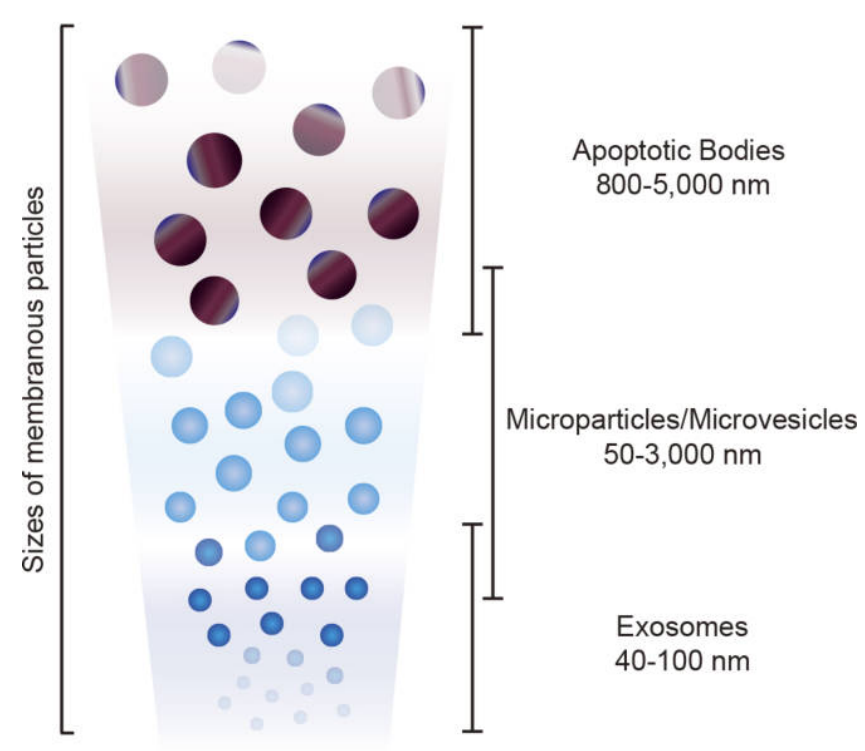

Fig. 2. Correlation between productive manner and diameter range of EVs. Exosomes are relatively small sized membranous particles (40-100 $\mathrm{nm})$, whereas apoptotic bodies are large vesicles $(800-5,000 \mathrm{~nm})$. Microparticles/microvesicles are reported as medium sized membranous globules (50-3,000 nm) among EVs. The distribution of diameters might overlap with each other.

(800-5,000 nm), are broken off from cells that are undergoing programmed cell death, and are also classified as a subclass of EVs (Fig. 1, Fig. 2 and Table I) (Beyer and Pisetsky, 2010; Kosaka et al., 2010; Morhayim et al., 2014).

\section{Bioactive molecules encapsulated in EVs}

A number of studies have demonstrated that RNA, DNA, and proteins are encapsulated in EVs as bioactive molecules (Table I) (Al-Nedawi et al., 2009; Cai et al., 2013; Waldenstrom et al., 2012; Yamamoto et al., 2015). Some reports have suggested that the bioactive molecules encapsulated in EVs play important roles in intercellular communication, and in specific signal transductions in the pathophysiological states of cells both in vitro and in vivo (Kawamoto et al., 2012; Tominaga et al., 2015; Yamamoto et al., 2015).

\section{Nucleotides}

Specific coding and non-coding RNAs such as mRNAs, miRNAs, retrotransposon RNAs, Alu transposable elements, and chromosomal DNA and mitochondrial DNA have been reported to be enriched in tumor cell-derived EVs (Balaj et al., 2011; Cai et al., 2013; Guescini et al., 2010; Rak and Guha, 2012; Ronquist et al., 2012; 
Table I. Classification and possible functions of EVs

\begin{tabular}{|c|c|c|c|c|c|}
\hline Classification & Biogenesis & Size & Contents & Functions & Related diseases \\
\hline $\begin{array}{l}\text { Membrane shedding type } \\
\text { EVs }\end{array}$ & $\begin{array}{l}\text { Budding from plasma } \\
\text { membrane and released } \\
\text { to the circulating blood } \\
\text { or interstitial fluid. }\end{array}$ & $50-3,000 \mathrm{~nm}$ & $\begin{array}{l}\text { mRNA, miRNA, } \\
\text { genomic DNA, } \\
\text { mitocondrial DNA, } \\
\text { protein, lipid, etc. }\end{array}$ & $\begin{array}{l}\text { Inflammation }{ }^{1} \text {, educating } \\
\text { recipient cell }^{1,2} \text {, promoting } \\
\text { hypercoagulability }^{3} \text {, thrombotic } \\
\text { activity }^{4} \text {, production of } \\
\text { inframmatory cytokines }^{5,6}, \\
\text { pulmonary oedema }^{7} \text {, enhance } \\
\text { permeabilization } \\
\text {, pulmonary } \\
\text { injury }{ }^{9} \text {, pulmonary } \\
\text { hypertension }^{10} \text {. }\end{array}$ & $\begin{array}{l}\text { Stroke }{ }^{11}, \text { myocardial } \\
\text { infarction }^{12}, \text { Kawasaki } \\
\text { disease }^{13,14}, \text { sepsis }^{15}, \\
\text { preeclampsia }^{16}, \\
\text { atherosclerosis }^{17}, \\
\text { diabetes mellitus }^{18}, \\
\text { metabolic syndrome }^{19} \text {, } \\
\text { cancer }^{20}, \text { infectious } \\
\text { disease }^{21} \text {. }\end{array}$ \\
\hline $\begin{array}{l}\text { Multivesicular body } \\
\text { derived EVs }\end{array}$ & $\begin{array}{l}\text { Produced in the cellular } \\
\text { endosome called } \\
\text { multivesiclur body. } \\
\text { Released to the blood } \\
\text { flow or interstitial fluid } \\
\text { as EVs when } \\
\text { multivesiclur body fuses } \\
\text { with plasma membrane. }\end{array}$ & $40-100 \mathrm{~nm}$ & $\begin{array}{l}\text { mRNA, miRNA, } \\
\text { genomic DNA, } \\
\text { mitocondrial DNA, } \\
\text { protein, lipid, etc. }\end{array}$ & $\begin{array}{l}\text { Leukotrien biogenesis }{ }^{22}, \\
\text { prostagrandin biogenesis }{ }^{23}, \\
\text { phosphatase activity }^{24}, \\
\text { educating recipient cell }{ }^{25}, \\
\text { angiogenesis }^{26,27}, \text { chemotaxis }^{22}, \\
\text { immunosuppression }^{23}, \text { tumor } \\
\text { suppressor }^{28}, \text { immune } \\
\text { evasion }^{29} \text {. }\end{array}$ & $\begin{array}{l}\text { Cancer }^{30,31} \text {, infectious } \\
\text { disease }^{21}, \text { heart failure } \\
\text { after acute myocardial } \\
\text { infarction }^{32}, \text { acute kidney } \\
\text { injury }^{33}, \text { acute podocyte } \\
\text { injury }{ }^{33}, \text { Alzheimer's } \\
\text { disease }^{34} \text {. }\end{array}$ \\
\hline Apoptosis derived EVs & $\begin{array}{l}\text { Broken off from cells } \\
\text { that are undergoing } \\
\text { programmed cell death. }\end{array}$ & $800-5,000 \mathrm{~nm}$ & $\begin{array}{l}\text { Oncoviral DNA, } \\
\text { genomic DNA, } \\
\text { protein, lipid, etc. }\end{array}$ & $\begin{array}{l}\text { Transferring oncoviral } \mathrm{DNA}^{35} \text {, } \\
\text { tumorigenic conversion } \\
\text { inappropriate clearance of } \\
\text { apoptotic derived } \mathrm{EVs}^{37} \text {. }\end{array}$ & $\begin{array}{l}\text { Autoimmune disease }{ }^{37} \text {, } \\
\text { viral infection }{ }^{35}\end{array}$ \\
\hline
\end{tabular}

References are described in Supplementary Information.

Waldenstrom et al., 2012). Recent studies have demonstrated that specific miRNAs encapsulated in EVs can educate the recipient cells through intercellular communication. We recently revealed that inflammation-related miRNAs are specifically encapsulated in endothelial-derived EVs (EEVs) in response to inflammatory stimuli (Yamamoto et al., 2015). We also demonstrated that E-EVs act as a tool for intercellular communication between endothelial cells and pericytes/vascular smooth muscle cells (vSMCs), in which inflammation-related miRNAs modulate mRNA expression of vascular endothelial growth factor, and mediate protein biogenesis in pericytes/vSMCs (Fig. 3). Along this line, miR-143/145 clusters contained in E-EVs were shown to control the vSMC phenotypes (Hergenreider et al., 2012). This study also suggested that reciprocal communication between endothelial cells and vSMCs through miRNAs contained in E-EVs plays an important role in protection from pathogenesis of atherosclerosis. These data suggest that cells can reciprocally communicate with other cells through small molecules encapsulated in EVs.

\section{Proteins}

Other studies suggest that specific proteins such as receptor type tyrosine kinases contained in EVs can transduce intracellular signals to the recipient cells (Al-Nedawi et al., 2009; Al-Nedawi et al., 2008). The blood vessels in tumors can be educated by EVs derived from tumor cells. Incorporation of EGF receptor-containing EVs into endothelial cells leads to the activation of MAPK and Akt pathways

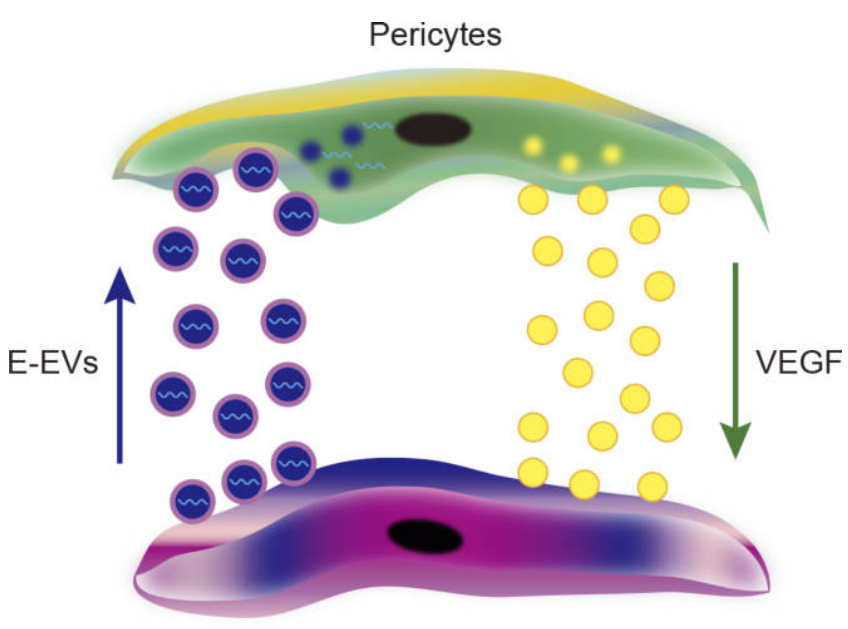

Inflamed endothelial cells

Fig. 3. Reciprocal intercellular communication. Under inflammatory conditions in endothelial cells, inflammation-related miRNAs are specifically encapsulated in E-EVs in response to inflammatory stimuli. The composition of inflammation-related miRNAs encapsulated in E-EVs might depend on the strength of inflammation (Yamamoto et al., 2015). When E-EVs are incorporated into pericytes/vSMCs, the inflammationrelated miRNAs modulate the mRNA expression levels of vascular endothelial growth factor, and mediate protein biogenesis in pericytes/ vSMCs. These reciprocal intercellular communications involving EVs might be common a biological intercellular response in pathophysiological conditions.

and triggers the endogenous expression of VEGF, followed by the activation of VEGFR2 (Al-Nedawi et al., 2009). 
EVs may contribute to the secretion of morphogens, and be responsible for their tissue gradient formation. Several lines of studies have shown that morphogens such as Dll4, Wnt, and Hedgehog (Beckett et al., 2013; Gross et al., 2012; Luga et al., 2012; Sheldon et al., 2010; Tanaka et al., 2005) tightly associate with the EV membrane surface. EVassociated Dll4 was incorporated to the recipient endothelial cells, and could inhibit Notch signaling in vitro. Such recipient endothelial cells reduced expression of the stalk cell markers, and appeared to switch the phenotype toward tip cells. (Sheldon et al., 2010). Regarding Wnt signaling, Wnt ligands bind to the EV surface through the cargo receptor, Evi/WIS, during Drosophila melanogaster development and in human cells (Gross et al., 2012). Wnts associated with EVs are implicated in signal transduction; however, EVs were unlikely to contribute essentially to the Wnt gradient formation in D. melanogaster (Beckett et al., 2013). In addition, EVs derived from fibroblasts can mediate autocrine Wnt signaling, and promote the cellular dynamics of tumor cells (Luga et al., 2012). In the pathological status of the central nervous system, pathogenic proteins involved in central nervous system diseases, such as $\beta$-amyloid peptide, superoxide dismutase, $\alpha$-synuclein, and prions (Emmanouilidou et al., 2010; Fevrier et al., 2004; Gomes et al., 2007; Rajendran et al., 2006), are also released in association with EVs.

\section{Clinical and pathobiological significance of EV $\boldsymbol{S}$}

In patients suffering from inflammation evoked by various diseases, EVs are often observed in the plasma and in other body fluids (Antonyak and Cerione, 2014; Koga et al., 2005; Nozaki et al., 2009; Simak et al., 2006), and the number of EVs are increased in response to the disease severity. These evidences may suggest that EVs are functionally active in the intercellular communication between EV-producing cells and other cells (Kawamoto et al., 2012; Yamamoto et al., 2015), and can be a potential biomarker for diagnosis, for response to medical treatment by therapeutic agents, and for prognosis (Table I) (Amabile et al., 2012; Fujita et al., 2014; Nozaki et al., 2009).

\section{Common diseases related to inflammation}

Clinically, EVs are often found in circulating blood, and the number of EVs is elevated in response to acute and chronic inflammation associating with common diseases such as stroke, myocardial infarction, Kawasaki disease, sepsis, preeclampsia, atherosclerosis, diabetes mellitus, and metabolic syndrome (Agouni et al., 2008; Boulanger et al., 2006; Ding et al., 2014; Koga et al., 2005; Mostefai et al., 2008; Petrozella et al., 2012; Simak et al., 2006; Tan et al., 2013). Nonetheless, EVs are produced by many types of cells in response to inflammation, vascular endothelial cells are thought to be one of the major cell types that release EVs into the bloodstream (Martinez et al., 2005). The number of E-EVs circulating in the bloodstream correlates with the disease severity (Boulanger et al., 2006). Several lines of study have suggested that regionally derived EVs are incorporated into remotely located cells (Ono et al., 2014; Peinado et al., 2012). Furthermore, we and others have demonstrated that cells under inflammatory conditions actively communicate with their adjacent cells through EVs (Hergenreider et al., 2012; Yamamoto et al., 2015). Accordingly, E-EVs may be functionally involved in the cellular communication in number of diseases; however, more evidence needs to be accumulated in in vivo models. Further clinical and experimental approaches are needed to elucidate the significance of EVs in inflammatory diseases.

\section{Infectious diseases}

It is necessary to pay careful attention to the crosstalk between host cells and pathogenic organisms in infectious diseases. EVs from the pathogenic organisms such as Trypanosoma spp., Cryptococcus spp., and Leishmania spp. may carry virulent factors and facilitate their delivery to host cells (Goncalves et al., 1991; Rodrigues et al., 2008; Silverman et al., 2010; Torrecilhas et al., 2012), subsequently promoting the dissemination of pathogens. In fact, proteomic analyses of parasite-produced EVs have identified virulent factors in EV proteomes (Bayer-Santos et al., 2013; Geiger et al., 2010; Silverman et al., 2010). Virulent factors in EVs such as proteases, toxins, and adhesins (Amano et al., 2010; Torrecilhas et al., 2012) are involved in the regulation of gene expression. Moreover, parasites have developed many strategies to survive and reproduce in host animals. One of the ingenious strategies employed by parasites is immune evasion (Lambertz et al., 2012) by establishment of self-tolerance, alteration of host antigens, immunosuppression and functional immune inactivation, and molecular mimicry between host antigens and parasite polypeptides by acquisition of sialic acid motifs from host cells and incorporation of sialoglycoconjugates from the host serum, which leads to modulation of host NETosis (Brinkmann et al., 2004; Hahn et al., 2013). Production of EVs by pathogenic organisms appears to be involved in many of these self-protection mechanisms.

\section{Cancer}

Cancer cells also secrete EVs in addition to the stromal cells from the tumor microenvironment. These secreted EVs contribute to tumor progression by promoting angiogenesis and tumor cell migration towards metastases (Hood et al., 2011; Rak, 2010). Some reports have a provided fascinating notion of tumor derived EVs. Tumor derived EVs can encapsulate and enrich coding and non-coding RNAs, 
retrotransposon RNAs, Alu transposable elements, and chromosomal and mitochondrial DNA (Balaj et al., 2011; Guescini et al., 2010; Rak and Guha, 2012; Ronquist et al., 2012; Waldenstrom et al., 2012). EVs from tumor cells can also crosstalk, reprogram, and permanently educate bone marrow progenitor cells to mobilize out from their niche (Peinado et al., 2012). Consistent with these contexts, vascular endothelial cells in tumors can be educated by EVs derived from tumor cells (Al-Nedawi et al., 2009; Kawamoto et al., 2012). Such educated vascular endothelial cells exhibited a highly proliferative phenotype and in some cases show endothelial karyotype abnormalities implying cellular immortality. Tumor-derived EVs also encapsulate immunosuppressive molecules that can inactivate natural killer cells or T-lymphocytes, or promote the differentiation of myeloid cells or regulatory $\mathrm{T}$ lymphocytes for suppressing immune responses (Zhang and Grizzle, 2011). These studies strongly suggest that EVbased cellular education is a universal phenomenon in pathophysiological conditions in vivo. These findings suggest that such "education" is mediated by specific miRNAs or proteins encapsulated in the EVs.

\section{Biomarker}

As a therapeutic biomarker, EVs may have the potential for prediction and prognosis of various diseases, particularly in cardiovascular diseases. Detectable levels of EVs from different cellular origins are commonly found to be circulating in the plasma of healthy humans. In cardiovascular functional disorders, although E-EVs represent a relatively small population of the circulating EVs in healthy humans, increase in their plasma levels may reflect important clinical information in patients (Chironi et al., 2009; DignatGeorge and Boulanger, 2011). Several studies have suggested that measurement of E-EVs from the plasma of patients with cardiovascular diseases has prognostic potential. In fact, a large number of E-EVs that express CD31 but not CD41 (platelet marker) might be a diagnostic biomarker for cardiovascular mortality, whereas such potential was not observed in EVs derived from other cell types (Amabile et al., 2012). In pulmonary hypertension, the number of circulating E-EVs expressing CD62E (Eselectin) can be used for predicting a one year outcome (Amabile et al., 2009). In case of acute ischemic stroke, EEV levels were associated with lesion volume and clinical outcome (Simak et al., 2004). In a high risk of coronary heart disease, the basal level of E-EVs that expressed CD144 (VE-cadherin) could predict the outcome independently of the Framingham score derived from C-reactive protein (CRP) and brain natriuretic peptide levels (Nozaki et al., 2009). Similar findings were observed in chronic renal failure. In the patient with Kawasaki disease, a significantly large number of E-EVs could be observed in the blood of patients, suggesting that E-EVs could be used as a potential biomarker for endothelial damage (Ding et al., 2014; Tan et al., 2013). These data suggest that E-EVs in plasma might be used in the future as a remarkable biomarker for the prediction of clinical stage in high-risk patients who may have cardiovascular complications.

\section{Conclusions and perspective}

Over the past decade, many studies have revealed abundant EVs that encapsulate many bioactive molecules in body fluids and show potent regulatory functions in target cells. These encapsulated molecules including RNAs and proteins are deeply correlated with the severity and malignancy of various diseases. It is obvious that EVs are a fascinating target for molecular-targeting therapeutic strategies to overcome various diseases. Thus, many scientists and physicians are focusing on EVs as a target for medical treatment, and as a prognostic and therapeutic biomarker. At the present time, however, technical difficulties hinder the progress of the field of EVs. Simple and accurate methods have not been established to discriminate among these EVs from clinical samples. Therefore, EVs need to be collected by ultracentrifugation, and column and solid phased methods, during research regarding the pathobiology of EVs. More simple, specific, and reproducible methods need to be established for the analysis of specific EVs in both clinical and basic research. Conducting of wider and deeper studies to develop methods for the specific detection and analysis of circulating EVs may help us to precisely understand the onset and progression of diseases. Further technical advances in this research field will open new avenues to clarify their respective functions.

\section{Authors' contributions}

SY involved in designing, coordinate and writing the manuscript, EA and MM involved in writing and improving the appearance of the manuscript, TH, YI and MS involved in revising the manuscript critically for important intellectual content. All authors read and approved the final manuscript.

Acknowledgments. We thank members of the Department of Pathology at the University of Toyama for helpful discussions. We also thank N. Yamamoto, A. Yamamoto, R. Yamamoto for broad-based support. This work was supported by a Grant-in-Aid for Scientific Research and Scientific Research on Innovative Areas (JP21590589/JP24659112 and JP23122506; to S.Y.) from the Ministry of Education, Culture, Sports, Science and Technology.

\section{References}

Agouni, A., Lagrue-Lak-Hal, A.H., Ducluzeau, P.H., Mostefai, H.A., Draunet-Busson, C., Leftheriotis, G., Heymes, C., Martinez, M.C., and 
Andriantsitohaina, R. 2008. Endothelial dysfunction caused by circulating microparticles from patients with metabolic syndrome. Am. J. Pathol., 173: 1210-1219.

Al-Nedawi, K., Meehan, B., Micallef, J., Lhotak, V., May, L., Guha, A., and Rak, J. 2008. Intercellular transfer of the oncogenic receptor EGFRvIII by microvesicles derived from tumour cells. Nat. Cell Biol., 10: 619-624.

Al-Nedawi, K., Meehan, B., Kerbel, R.S., Allison, A.C., and Rak, J. 2009. Endothelial expression of autocrine VEGF upon the uptake of tumorderived microvesicles containing oncogenic EGFR. Proc. Natl. Acad. Sci. USA, 106: 3794-3799.

Amabile, N., Heiss, C., Chang, V., Angeli, F.S., Damon, L., Rame, E.J., McGlothlin, D., Grossman, W., De Marco, T., and Yeghiazarians, Y. 2009. Increased $\mathrm{CD} 62 \mathrm{e}(+)$ endothelial microparticle levels predict poor outcome in pulmonary hypertension patients. J. Heart Lung Transplant., 28: $1081-1086$.

Amabile, N., Guerin, A.P., Tedgui, A., Boulanger, C.M., and London, G.M. 2012. Predictive value of circulating endothelial microparticles for cardiovascular mortality in end-stage renal failure: a pilot study. Nephrol. Dial. Transplant., 27: 1873-1880.

Amano, A., Takeuchi, H., and Furuta, N. 2010. Outer membrane vesicles function as offensive weapons in host-parasite interactions. Microbes Infect., 12: 791-798.

Antonyak, M.A. and Cerione, R.A. 2014. Microvesicles as mediators of intercellular communication in cancer. Methods Mol. Biol., 1165: 147173.

Balaj, L., Lessard, R., Dai, L., Cho, Y.J., Pomeroy, S.L., Breakefield, X.O., and Skog, J. 2011. Tumour microvesicles contain retrotransposon elements and amplified oncogene sequences. Nat. Commun., 2: 180.

Bayer-Santos, E., Aguilar-Bonavides, C., Rodrigues, S.P., Cordero, E.M., Marques, A.F., Varela-Ramirez, A., Choi, H., Yoshida, N., da Silveira, J.F., and Almeida, I.C. 2013. Proteomic analysis of Trypanosoma cruzi secretome: characterization of two populations of extracellular vesicles and soluble proteins. J. Proteome Res, 12: 883-897.

Beckett, K., Monier, S., Palmer, L., Alexandre, C., Green, H., Bonneil, E., Raposo, G., Thibault, P., Le Borgne, R., and Vincent, J.P. 2013. Drosophila $\mathrm{S} 2$ cells secrete wingless on exosome-like vesicles but the wingless gradient forms independently of exosomes. Traffic, 14: 82-96.

Beyer, C. and Pisetsky, D.S. 2010. The role of microparticles in the pathogenesis of rheumatic diseases. Nat. Rev. Rheumatol., 6: 21-29.

Boulanger, C.M., Amabile, N., and Tedgui, A. 2006. Circulating microparticles: a potential prognostic marker for atherosclerotic vascular disease. Hypertension, 48: 180-186.

Brinkmann, V., Reichard, U., Goosmann, C., Fauler, B., Uhlemann, Y., Weiss, D.S., Weinrauch, Y., and Zychlinsky, A. 2004. Neutrophil extracellular traps kill bacteria. Science, 303: 1532-1535.

Cai, J., Han, Y., Ren, H., Chen, C., He, D., Zhou, L., Eisner, G.M., Asico, L.D., Jose, P.A., and Zeng, C. 2013. Extracellular vesicle-mediated transfer of donor genomic DNA to recipient cells is a novel mechanism for genetic influence between cells. J. Mol. Cell Biol., 5: 227-238.

Chironi, G.N., Boulanger, C.M., Simon, A., Dignat-George, F., Freyssinet, J.M., and Tedgui, A. 2009. Endothelial microparticles in diseases. Cell Tissue Res., 335: 143-151.

Dignat-George, F. and Boulanger, C.M. 2011. The many faces of endothelial microparticles. Arterioscler. Thromb. Vasc. Biol., 31: 27-33.

Ding, Y.Y., Ren, Y., Feng, X., Xu, Q.Q., Sun, L., Zhang, J.M., Dou, J.J., Lv, H.T., and Yan, W.H. 2014. Correlation between brachial artery flow-mediated dilation and endothelial microparticle levels for identifying endothelial dysfunction in children with Kawasaki disease. Pediatr. Res., 75: 453-458.

Emmanouilidou, E., Melachroinou, K., Roumeliotis, T., Garbis, S.D., Ntzouni, M., Margaritis, L.H., Stefanis, L., and Vekrellis, K. 2010. Cell-produced alpha-synuclein is secreted in a calcium-dependent man- ner by exosomes and impacts neuronal survival. J. Neurosci., 30: 68386851.

Fevrier, B., Vilette, D., Archer, F., Loew, D., Faigle, W., Vidal, M., Laude, H., and Raposo, G. 2004. Cells release prions in association with exosomes. Proc. Natl. Acad. Sci. USA, 101: 9683-9688.

Fujita, Y., Kuwano, K., Ochiya, T., and Takeshita, F. 2014. The impact of extracellular vesicle-encapsulated circulating microRNAs in lung cancer research. Biomed. Res. Int., 2014: 486413.

Geiger, A., Hirtz, C., Becue, T., Bellard, E., Centeno, D., Gargani, D., Rossignol, M., Cuny, G., and Peltier, J.B. 2010. Exocytosis and protein secretion in Trypanosoma. BMC Microbiol., 10: 20.

Gomes, C., Keller, S., Altevogt, P., and Costa, J. 2007. Evidence for secretion of $\mathrm{Cu}, \mathrm{Zn}$ superoxide dismutase via exosomes from a cell model of amyotrophic lateral sclerosis. Neurosci. Lett., 428: 43-46.

Goncalves, M.F., Umezawa, E.S., Katzin, A.M., de Souza, W., Alves, M.J., Zingales, B., and Colli, W. 1991. Trypanosoma cruzi: shedding of surface antigens as membrane vesicles. Exp. Parasitol., 72: 43-53.

Gould, S.J. and Raposo, G. 2013. As we wait: coping with an imperfect nomenclature for extracellular vesicles. J. Extracell. Vesicles, 2.

Gross, J.C., Chaudhary, V., Bartscherer, K., and Boutros, M. 2012. Active Wnt proteins are secreted on exosomes. Nat. Cell Biol., 14: 1036-1045.

Gruenberg, J. and van der Goot, F.G. 2006. Mechanisms of pathogen entry through the endosomal compartments. Nat. Rev. Mol. Cell Biol., 7: 495-504.

Guescini, M., Genedani, S., Stocchi, V., and Agnati, L.F. 2010. Astrocytes and Glioblastoma cells release exosomes carrying mtDNA. J. Neural Transm., 117: 1-4.

Gyorgy, B., Szabo, T.G., Pasztoi, M., Pal, Z., Misjak, P., Aradi, B., Laszlo, V., Pallinger, E., Pap, E., Kittel, A., Nagy, G., Falus, A., and Buzas, E.I. 2011. Membrane vesicles, current state-of-the-art: emerging role of extracellular vesicles. Cell. Mol. Life Sci., 68: 2667-2688.

Hahn, S., Giaglis, S., Chowdhury, C.S., Hosli, I., and Hasler, P. 2013. Modulation of neutrophil NETosis: interplay between infectious agents and underlying host physiology. Semin. Immunopathol., 35: 439-453.

Hergenreider, E., Heydt, S., Treguer, K., Boettger, T., Horrevoets, A.J., Zeiher, A.M., Scheffer, M.P., Frangakis, A.S., Yin, X., Mayr, M., Braun, T., Urbich, C., Boon, R.A., and Dimmeler, S. 2012. Atheroprotective communication between endothelial cells and smooth muscle cells through miRNAs. Nat. Cell Biol., 14: 249-256.

Hood, J.L., San, R.S., and Wickline, S.A. 2011. Exosomes released by melanoma cells prepare sentinel lymph nodes for tumor metastasis. Cancer Res., 71: 3792-3801.

Johnstone, R.M., Adam, M., Hammond, J.R., Orr, L., and Turbide, C. 1987. Vesicle formation during reticulocyte maturation. Association of plasma membrane activities with released vesicles (exosomes). J. Biol. Chem., 262: 9412-9420.

Kalra, H., Simpson, R.J., Ji, H., Aikawa, E., Altevogt, P., Askenase, P., Bond, V.C., Borras, F.E., Breakefield, X., Budnik, V., Buzas, E., Camussi, G., Clayton, A., Cocucci, E., Falcon-Perez, J.M., Gabrielsson, S., Gho, Y.S., Gupta, D., Harsha, H.C., Hendrix, A., Hill, A.F., Inal, J.M., Jenster, G., Kramer-Albers, E.M., Lim, S.K., Llorente, A., Lotvall, J., Marcilla, A., Mincheva-Nilsson, L., Nazarenko, I., Nieuwland, R., Nolte-'t Hoen, E.N., Pandey, A., Patel, T., Piper, M.G., Pluchino, S., Prasad, T.S., Rajendran, L., Raposo, G., Record, M., Reid, G.E., Sanchez-Madrid, F., Schiffelers, R.M., Siljander, P., Stensballe, A., Stoorvogel, W., Taylor, D., Thery, C., Valadi, H., van Balkom, B.W., Vazquez, J., Vidal, M., Wauben, M.H., Yanez-Mo, M., Zoeller, M., and Mathivanan, S. 2012. Vesiclepedia: a compendium for extracellular vesicles with continuous community annotation. PLoS Biol., 10: e1001450.

Kawamoto, T., Ohga, N., Akiyama, K., Hirata, N., Kitahara, S., Maishi, N., Osawa, T., Yamamoto, K., Kondoh, M., Shindoh, M., Hida, Y., and Hida, K. 2012. Tumor-derived microvesicles induce proangiogenic 
phenotype in endothelial cells via endocytosis. PLoS One, 7: e34045.

Koga, H., Sugiyama, S., Kugiyama, K., Watanabe, K., Fukushima, H., Tanaka, T., Sakamoto, T., Yoshimura, M., Jinnouchi, H., and Ogawa, H. 2005. Elevated levels of VE-cadherin-positive endothelial microparticles in patients with type 2 diabetes mellitus and coronary artery disease. J. Am. Coll. Cardiol., 45: 1622-1630.

Kosaka, N., Iguchi, H., and Ochiya, T. 2010. Circulating microRNA in body fluid: a new potential biomarker for cancer diagnosis and prognosis. Cancer Sci., 101: 2087-2092.

Lambertz, U., Silverman, J.M., Nandan, D., McMaster, W.R., Clos, J., Foster, L.J., and Reiner, N.E. 2012. Secreted virulence factors and immune evasion in visceral leishmaniasis. J. Leukoc. Biol., 91: 887899.

Leroyer, A.S., Isobe, H., Leseche, G., Castier, Y., Wassef, M., Mallat, Z., Binder, B.R., Tedgui, A., and Boulanger, C.M. 2007. Cellular origins and thrombogenic activity of microparticles isolated from human atherosclerotic plaques. J. Am. Coll. Cardiol., 49: 772-777.

Luga, V., Zhang, L., Viloria-Petit, A.M., Ogunjimi, A.A., Inanlou, M.R., Chiu, E., Buchanan, M., Hosein, A.N., Basik, M., and Wrana, J.L. 2012. Exosomes mediate stromal mobilization of autocrine Wnt-PCP signaling in breast cancer cell migration. Cell, 151: 1542-1556.

Martinez, M.C., Tesse, A., Zobairi, F., and Andriantsitohaina, R. 2005. Shed membrane microparticles from circulating and vascular cells in regulating vascular function. Am. J. Physiol. Heart Circ. Physiol., 288: H1004-1009.

Morhayim, J., Baroncelli, M., and van Leeuwen, J.P. 2014. Extracellular vesicles: specialized bone messengers. Arch. Biochem. Biophys., 561: $38-45$.

Mostefai, H.A., Meziani, F., Mastronardi, M.L., Agouni, A., Heymes, C., Sargentini, C., Asfar, P., Martinez, M.C., and Andriantsitohaina, R. 2008. Circulating microparticles from patients with septic shock exert protective role in vascular function. Am. J. Respir. Crit. Care Med., 178: $1148-1155$.

Nozaki, T., Sugiyama, S., Koga, H., Sugamura, K., Ohba, K., Matsuzawa, Y., Sumida, H., Matsui, K., Jinnouchi, H., and Ogawa, H. 2009. Significance of a multiple biomarkers strategy including endothelial dysfunction to improve risk stratification for cardiovascular events in patients at high risk for coronary heart disease. J. Am. Coll. Cardiol., 54: 601-608.

Ono, M., Kosaka, N., Tominaga, N., Yoshioka, Y., Takeshita, F., Takahashi, R.U., Yoshida, M., Tsuda, H., Tamura, K., and Ochiya, T. 2014. Exosomes from bone marrow mesenchymal stem cells contain a microRNA that promotes dormancy in metastatic breast cancer cells. Sci. Signal., 7: ra63.

Peinado, H., Aleckovic, M., Lavotshkin, S., Matei, I., Costa-Silva, B., Moreno-Bueno, G., Hergueta-Redondo, M., Williams, C., GarciaSantos, G., Ghajar, C., Nitadori-Hoshino, A., Hoffman, C., Badal, K., Garcia, B.A., Callahan, M.K., Yuan, J., Martins, V.R., Skog, J., Kaplan, R.N., Brady, M.S., Wolchok, J.D., Chapman, P.B., Kang, Y., Bromberg, J., and Lyden, D. 2012. Melanoma exosomes educate bone marrow progenitor cells toward a pro-metastatic phenotype through MET. Nat. Med., 18: 883-891.

Petrozella, L., Mahendroo, M., Timmons, B., Roberts, S., McIntire, D., and Alexander, J.M. 2012. Endothelial microparticles and the antiangiogenic state in preeclampsia and the postpartum period. Am. J. Obstet. Gynecol., 207: 140 e120-146.

Rajendran, L., Honsho, M., Zahn, T.R., Keller, P., Geiger, K.D., Verkade, P., and Simons, K. 2006. Alzheimer's disease beta-amyloid peptides are released in association with exosomes. Proc. Natl. Acad. Sci. USA, 103: $11172-11177$.

Rak, J. 2010. Microparticles in cancer. Semin. Thromb. Hemost., 36: 888906.
Rak, J. and Guha, A. 2012. Extracellular vesicles--vehicles that spread cancer genes. Bioessays, 34: 489-497.

Raposo, G. and Stoorvogel, W. 2013. Extracellular vesicles: exosomes, microvesicles, and friends. J. Cell Biol., 200: 373-383.

Rodrigues, M.L., Nakayasu, E.S., Oliveira, D.L., Nimrichter, L., Nosanchuk, J.D., Almeida, I.C., and Casadevall, A. 2008. Extracellular vesicles produced by Cryptococcus neoformans contain protein components associated with virulence. Eukaryot. Cell, 7: 58-67.

Ronquist, G.K., Larsson, A., Stavreus-Evers, A., and Ronquist, G. 2012. Prostasomes are heterogeneous regarding size and appearance but affiliated to one DNA-containing exosome family. Prostate, 72: 1736-1745.

Sheldon, H., Heikamp, E., Turley, H., Dragovic, R., Thomas, P., Oon, C.E., Leek, R., Edelmann, M., Kessler, B., Sainson, R.C., Sargent, I., Li, J.L., and Harris, A.L. 2010. New mechanism for Notch signaling to endothelium at a distance by Delta-like 4 incorporation into exosomes. Blood, 116: 2385-2394.

Silverman, J.M., Clos, J., de'Oliveira, C.C., Shirvani, O., Fang, Y., Wang, C., Foster, L.J., and Reiner, N.E. 2010. An exosome-based secretion pathway is responsible for protein export from Leishmania and communication with macrophages. J. Cell Sci., 123: 842-852.

Simak, J., Holada, K., Risitano, A.M., Zivny, J.H., Young, N.S., and Vostal, J.G. 2004. Elevated circulating endothelial membrane microparticles in paroxysmal nocturnal haemoglobinuria. Br. J. Haematol., 125: 804-813.

Simak, J., Gelderman, M.P., Yu, H., Wright, V., and Baird, A.E. 2006. Circulating endothelial microparticles in acute ischemic stroke: a link to severity, lesion volume and outcome. J. Thromb. Haemost., 4: 12961302

Steller, H. 1995. Mechanisms and genes of cellular suicide. Science, 267: 1445-1449.

Tan, Z., Yuan, Y., Chen, S., Chen, Y., and Chen, T.X. 2013. Plasma Endothelial Microparticles, TNF-a and IL-6 in Kawasaki Disease. Indian Pediatr., 50: 501-503.

Tanaka, Y., Okada, Y., and Hirokawa, N. 2005. FGF-induced vesicular release of Sonic hedgehog and retinoic acid in leftward nodal flow is critical for left-right determination. Nature, 435: 172-177.

Tominaga, N., Kosaka, N., Ono, M., Katsuda, T., Yoshioka, Y., Tamura, K., Lotvall, J., Nakagama, H., and Ochiya, T. 2015. Brain metastatic cancer cells release microRNA-181c-containing extracellular vesicles capable of destructing blood-brain barrier. Nat. Commun., 6: 6716.

Torrecilhas, A.C., Schumacher, R.I., Alves, M.J., and Colli, W. 2012 Vesicles as carriers of virulence factors in parasitic protozoan diseases. Microbes Infect., 14: 1465-1474.

Waldenstrom, A., Genneback, N., Hellman, U., and Ronquist, G. 2012. Cardiomyocyte microvesicles contain DNA/RNA and convey biological messages to target cells. PLoS One, 7: e34653.

Wolf, P. 1967. The nature and significance of platelet products in human plasma. Br. J. Haematol., 13: 269-288.

Yamamoto, S., Niida, S., Azuma, E., Yanagibashi, T., Muramatsu, M., Huang, T.T., Sagara, H., Higaki, S., Ikutani, M., Nagai, Y., Takatsu, K., Miyazaki, K., Hamashima, T., Mori, H., Matsuda, N., Ishii, Y., and Sasahara, M. 2015. Inflammation-induced endothelial cell-derived extracellular vesicles modulate the cellular status of pericytes. Sci. Rep., 5: 8505.

Zhang, H.G. and Grizzle, W.E. 2011. Exosomes and cancer: a newly described pathway of immune suppression. Clin. Cancer Res., 17: 959964.

(Received for publication, August 5, 2016, accepted, September 21, 2016 and published online, September 29, 2016) 